\title{
Structure and Ligand Selection of Hemoglobin II from Lucina pectinata*[5
}

Received for publication, June 19, 2007, and in revised form, January 10, 2008 Published, JBC Papers in Press, January 18, 2008, DOI 10.1074/jbc.M705026200

\author{
José A. Gavira ${ }^{\ddagger}$, Ana Camara-Artigas ${ }^{\S}$, Walleska De Jesús-Bonilla", Juan López-Garriga" , Ariel Lewis", Ruth Pietri", \\ Syun-Ru Yeh", Carmen L. Cadilla**, and Juan Manuel García-Ruiz ${ }^{*}$ \\ From the ${ }^{\ddagger}$ Laboratorio de Estudios Cristalográficos, CSIC, P.T. Ciencias de la Salud, 18100, Granada, Spain, the ${ }^{\S}$ Department of \\ Química-Física, Bioquímica y Química Inorgánica, Universidad de Almería, Carretera Sacramento, Almería, 04120, Spain, \\ "Chemistry Department, P. O. Box 9019, University of Puerto Rico, Mayagüez Campus, Mayagüez 00681, Puerto Rico, the \\ "Department of Physiology and Biophysics, Albert Einstein College of Medicine, Bronx, New York 10461, and \\ the **Bochemistry Department, Medical Sciences Campus, University of Puerto Rico, San Juan, Puerto Rico 00936
}

Lucina pectinata ctenidia harbor three heme proteins: sulfide-reactive hemoglobin $\mathrm{I}\left(\mathrm{HbI}_{L p}\right)$ and the oxygen transporting hemoglobins II and III $\left(\mathrm{HbII}_{L p}\right.$ and $\left.\mathrm{HbIII}_{L p}\right)$ that remain unaffected by the presence of $\mathrm{H}_{2} \mathrm{~S}$. The mechanisms used by these three proteins for their function, including ligand control, remain unknown. The crystal structure of oxygen-bound $\mathrm{HbII}_{L p}$ shows a dimeric oxyHbII ${ }_{L p}$ where oxygen is tightly anchored to the heme through hydrogen bonds with $\operatorname{Tyr}^{30}(\mathrm{~B} 10)$ and $\mathrm{Gln}^{65}$ (E7). The heme group is buried farther within $\mathrm{HbII}_{L p}$ than in $\mathrm{HbI}_{L p}$. The proximal His ${ }^{97}(\mathrm{~F} 8)$ is hydrogen bonded to a water molecule, which interacts electrostatically with a propionate group, resulting in a Fe-His vibration at $211 \mathrm{~cm}^{-1}$. The combined effects of the $\mathrm{HbII}_{L p}$ small heme pocket, the hydrogen bonding network, the $\mathrm{His}^{97}$ trans-effect, and the orientation of the oxygen molecule confer stability to the oxy-HbII ${ }_{L p}$ complex. Oxidation of $\mathrm{HbI}_{L p}$ Phe(B10) $\rightarrow$ Tyr and $\mathrm{HbII}_{L p}$ only occurs when the $\mathrm{pH}$ is decreased from $\mathrm{pH} 7.5$ to 5.0. Structural and resonance Raman spectroscopy studies suggest that $\mathrm{HbII}_{L p}$ oxygen binding and transport to the host bacteria may be regulated by the dynamic displacements of the $\mathrm{Gln}^{65}(\mathrm{E} 7)$ and $\mathrm{Tyr}^{30}(\mathrm{~B} 10)$ pair toward the heme to protect it from changes in the heme oxidation state from $\mathrm{Fe}^{\mathrm{II}}$ to $\mathrm{Fe}^{\mathrm{III}}$.

Hemoglobins are key proteins in symbiotic relationships between invertebrates and chemoautotrophic bacteria. The

\footnotetext{
* This work was supported by National Science Foundation Grant NSF-MCB0544250 (to J. L. G.), National Institutes of Health NIGMS MBRS-SCORE 2 Grant S06GM08103-34 (to J. L. G.), Grants P20RR016470 and G12RR03051 from the National Center for Research Resources, National Institutes of Health, Grant BIO2006-15517-C02-02 from the Spanish Ministry of Education and Sciences, Project RMN-1344, the Junta de Andalucía (Spain) (J. A. G.), Factoría de Cristalización funded by the program ConsoliderIngenio 2010, and National Institutes of Health Grant HL65465 (to S. R. Y.). The costs of publication of this article were defrayed in part by the payment of page charges. This article must therefore be hereby marked "advertisement" in accordance with 18 U.S.C. Section 1734 solely to indicate this fact.

The atomic coordinates and structure factors (code 2OLP) have been deposited in the Protein Data Bank, Research Collaboratory for structural Bioinformatics, Rutgers University, New Brunswick, NJ (http://www.rcsb.org/).

5 The on-line version of this article (available at http://www.jbc.org) contains supplemental Figs. S1 and S2.

${ }^{1}$ To whom correspondence should be addressed: P. O. Box 9019, University of Puerto Rico, Mayagüez Campus, Mayagüez, Puerto Rico 00681. Fax: 787265-5476; E-mail: lopezj@uprm.edu.
}

clam Lucina pectinata inhabits the sulfide-rich tropical mud and produces three different types of hemoglobin in its gills, first described by Read (1) and characterized by Kraus and Wittenberg (2, 3). Different functionalities have been described for the three hemoglobin variants: hemoglobin I $\left(\mathrm{HbI}_{L p}\right)^{2}$ is a sulfide-reactive monomeric protein, whereas hemoglobin II and III ( $\mathrm{HbII}_{L p}$ and $\mathrm{HbIII}_{L p}$ ) are oxygen transporters. $\mathrm{HbII}_{L p}$ and $\mathrm{HbIII}_{L p}$ self-associate in a concentrationdependent manner forming a tetramer that remains unaffected in the presence of $\mathrm{H}_{2} \mathrm{~S}(2,3)$. The mechanisms underlying ligand selection control between $\mathrm{HbI}_{L p}$ and $\mathrm{HbII}_{L p} / \mathrm{HbIII}_{L p}$ remain unknown. The structure of $\mathrm{HbI}_{L p}$ has been solved with different ligands bound at the distal position: water (Protein Data Bank code 1FLP) (4), cyanide (PDB code $1 \mathrm{BOB}$ ) (5), and hydrosulfuric acid (PDB code $1 \mathrm{MOH}$ ) (6). The primary structure of $\mathrm{HbII}_{L p}$ was determined by Edman degradation (7) and from its cDNA sequence (8). $\mathrm{HbI}_{L p}$ only shares $32 \%$ of its amino acid sequence with $\mathrm{HbII}_{L p}$, but both have a conserved glutamine in the E7 position, and a phenylalanine and a tyrosine in the $\mathrm{B} 10$ position for $\mathrm{HbI}_{L p}$ and $\mathrm{HbII}_{L p}$, respectively. The $\operatorname{Tyr}(\mathrm{B} 10)$ and $\mathrm{G} \ln (\mathrm{E} 7)$ distal heme pocket residues of $\mathrm{HbII}_{L p}$ are also found in other hemoglobins $(8,9)$. Hemoglobins from Ascaris suum $\left(\mathrm{Hb}_{\text {Asc }}\right)(\operatorname{Tyr}(\mathrm{B} 10)$ and $\mathrm{Gln}(\mathrm{E} 7))(10)$ and Mycobacterium tuberculosis hemoglobin $\mathrm{N}(\operatorname{Tyr}(\mathrm{B} 10)$ and Leu(E7)) $(11,12)$ show high oxygen affinity and a very slow release of the bound oxygen. The three different hemoglobins from the clam Scapharca inaequivalvis $\left(\mathrm{Hb}_{S i}\right)$ show a very different heme pocket $(\operatorname{Met}(\mathrm{B} 10)$ and $\mathrm{His}(\mathrm{E} 7))(13) . \mathrm{Hb}_{\mathrm{IIA}},{ }_{S i}$ and $\mathrm{Hb}_{\mathrm{IIB}},{ }_{S i}$, assemble to form a heterotetramer (like $\mathrm{HbII}_{L p}$ and $\mathrm{HbIII}_{L p}$ ), whereas $\mathrm{Hb}_{\mathrm{I}}$, Si forms homodimers (like $\mathrm{HbII}_{L p}$ ). The different types of hemoglobin from this clam bind oxygen cooperatively. $\mathrm{Hb}_{\mathrm{IIB}}$, ${ }_{S i}$ exhibits a Hill coefficient for oxygen binding of 2.1 when in a heterotetramer, whereas the homodimer has a Hill coefficient of 1.5 (14). Interestingly, even though the S. inaequivalvis hemoglobins and L. pectinata $\mathrm{HbII}_{L p}$ and $\mathrm{HbIII}_{L p}$ share $\geq 40 \%$ amino acid similarity, the Lucina hemoglobins do not behave cooperatively (2).

\footnotetext{
2 The abbreviations used are: $\mathrm{Hb}_{L p}$, L. pectinata hemoglobin; $\mathrm{Hb}_{A s C^{\prime}}$ A. suum hemoglobin; $\mathrm{Hb}_{S i}$ S. inaequivalvis hemoglobin; $\mathrm{Hblr}$, L. pectinata recombinant $\mathrm{Hbl}$; trHb, truncated hemoglobins; FPLC, fast performance liquid chromatography; BisTris, 2-[bis(2-hydroxyethyl)amino]-2-(hydroxymethyl)propane-1,3-diol.
} 


\section{L. pectinata Hbll Structure}

Early biophysical studies (15) compared the structure and functionality of $\mathrm{HbII}_{L p}$ and hemoglobin from A. suum because both heme proteins have heme pockets with $\operatorname{Tyr}(\mathrm{B} 10)$ and $\mathrm{Gln}(\mathrm{E} 7)$. The low oxygen off rates were attributed to differences in the hydrogen bonding network of both oxy-protein complexes. Additional studies using UV-visible spectroscopy and $\mathrm{pH}$ titration of $\mathrm{HbII}_{L p}$ and a $\mathrm{HbI}_{L p} \mathrm{Phe}(\mathrm{B} 10) \rightarrow$ Tyr mutant have revealed bands at 486, 541,577, and $603 \mathrm{~nm}$ for both proteins at neutral conditions $(3,9)$. At basic $\mathrm{pH}$ values, the barrier for the reaction increases as the tyrosine adopts a closed conformation and the heme $\left(\mathrm{Fe}^{\mathrm{III}}\right)$ hydroxyl complex replaces the met-aquo species, which suggested the existence of an open and closed conformation due to the interactions between $\operatorname{Tyr}(\mathrm{B} 10)$ and the heme iron. The presence of these conformers were confirmed by resonance Raman spectroscopy showing that, in a neutral environment, met-aquo $\mathrm{HbII}_{L p}$ was present as a mixture of coordination and spin states with values for the $v_{2}$ mode at $1558 \mathrm{~cm}^{-1}$ (6C HS) and $1580 \mathrm{~cm}^{-1}$ (6C LS) and for the $v_{3}$ mode at $1479 \mathrm{~cm}^{-1}$ (6C HS), $1492 \mathrm{~cm}^{-1}$ (5C), and $1503 \mathrm{~cm}^{-1}$ (6C LS) (9). The infrared spectra of the complex $\mathrm{HbII}_{L p} \mathrm{CO}$ also showed the presence of the $\mathrm{A}_{3}$ (closed) and $\mathrm{A}_{0}$ (open) conformers at 1924 and $1964 \mathrm{~cm}^{-1}$, respectively (9). We proposed that in the open conformation $\operatorname{Tyr}(\mathrm{B} 10)$ swings away from the heme iron, whereas in the closed conformation $\operatorname{Tyr}(\mathrm{B} 10)$ is closer to and may interact with the ligand. Similarly, the reactions between hydrogen peroxide and both $\mathrm{HbII}_{L p}$ and the $\mathrm{HbI}_{L p}$ Phe(B10) $\rightarrow$ Tyr mutant showed that $\operatorname{Tyr}(\mathrm{B} 10)$ tailors, in two very distinct ways, the reactivity of compounds I and II ferryl species (9). First, increasing the reaction $\mathrm{pH}$ from 4.9 to 7.5 , and then to 11.2 , the second order rate constant for $\mathrm{HbII}_{L P}$ decreases from 141.60 to $77.78 \mathrm{M}^{-1} \mathrm{~s}^{-1}$, and to $2.96 \mathrm{M}^{-1} \mathrm{~s}^{-1}$, respectively. This $\mathrm{pH}$ dependence is associated with the disruption of the heme-tyrosine $(603 \mathrm{~nm})$ protein moiety, which controls access of $\mathrm{H}_{2} \mathrm{O}_{2}$ to the heme protein active center, thus regulating the formation of the ferryl species. Second, the existence of a hydrogen bonding network between the heme pocket amino acids (i.e. $\operatorname{Tyr}(\mathrm{B} 10)$ ) and ferryl compound I created a much faster path than $3.0 \times 10^{-2} \mathrm{~s}^{-1}$ for the decay of compound I to compound II. Moreover, the presence of $\operatorname{Tyr}(\mathrm{B} 10)$ in $\mathrm{HbII}_{L p}$ and the $\mathrm{HbI}_{L p} \mathrm{Phe}(\mathrm{B} 10) \rightarrow$ Tyr mutant appears to afford a more stable $\mathrm{O}_{2}$ adduct in the oxygenated $\mathrm{HbI}_{L p}$. The contribution of $\operatorname{Tyr}(\mathrm{B} 10)$ to the stability of the $\mathrm{HbII}_{L p}$ and $\mathrm{HbI}_{L p}$ Phe(B10) $\rightarrow$ Tyr heme pocket against peroxide attack has recently been shown to be partially due to the presence of hydrogen bonding between the ferryl moiety and the heme pocket amino acids, including $\operatorname{Tyr}(\mathrm{B} 10)$, which ultimately enhances the removal of peroxide by the peroxidative cycle (16, 17). In addition, the close proximity of $\mathrm{Tyr}(\mathrm{B} 10)$ with $\mathrm{G} \ln (\mathrm{E} 7)$ to the heme iron contributes largely to the distal control of NO binding, thus providing a model for the design of future oxidative stable oxygen hemoglobins with little or no vasoactivity (16).

Here, we report detailed structural data of $\mathrm{HbII}_{L p}$ obtained by $x$-ray crystallography, providing information about the heme pocket, distal amino acids, and their interaction with the dioxygen molecule. Our results, supported by resonance Raman measurements, suggest a mechanism where $\mathrm{HbII}_{L p}$ selects oxygen by tailoring the hydrogen bonding environment between the $\operatorname{Tyr}(\mathrm{B} 10)$ and $\mathrm{Gln}(\mathrm{E} 7)$ and heme- $\mathrm{O}_{2}$ moiety, stabilizing the heme $\left(\mathrm{Fe}^{\mathrm{II}}\right)$ oxidation state.

\section{EXPERIMENTAL PROCEDURES}

Wild-type $\mathrm{HbI}_{L p}$ and $\mathrm{HbII}_{L p}$ Sample Preparations-Proteins were isolated and purified as described with minor modifications (9). $\mathrm{HbI}_{L p}$ was separated from $\mathrm{HbII}_{L p} / \mathrm{HbIII}_{L p}$ using a $\mathrm{Hi}$ Load 26/60 Superdex 200 gel filtration column (AKTA FPLC, Amersham Biosciences). $\mathrm{HbI}_{L p}$ was further purified by cation exchange chromatography using DEAE Sephadex Fast Flow equilibrated with $25 \mathrm{~mm}$ ammonium bicarbonate buffer, $\mathrm{pH}$ 8.3. $\mathrm{HbII}_{L p}$ was purified from the $\mathrm{HbII}_{L p} / \mathrm{HbIII}_{L p}$ fraction by ion exchange chromatography with a HiPrep 16/10 Q FF column equilibrated with $10 \mathrm{~mm}$ triethanolamine/acetate buffer at $\mathrm{pH}$ 8.3 and eluted with a gradient of sodium chloride concentration from 0 to $180 \mathrm{~mm}$. The purity of the proteins was confirmed by SDS-PAGE.

Recombinant $\mathrm{HbI}_{L p}$ and Site-directed Mutant PreparationThe mutants from L. pectinata $\mathrm{HbI}\left(\mathrm{HbI}_{L p} \mathrm{Phe}(\mathrm{B} 10) \rightarrow \mathrm{Tyr}\right.$, $\mathrm{HbI}_{L p} \mathrm{Gln}(\mathrm{E} 7) \mathrm{Val}, \mathrm{HbI}_{L p} \mathrm{Gln}(\mathrm{E} 7) \rightarrow$ Asn, and $\mathrm{HbI}_{L p} \mathrm{Gln}(\mathrm{E} 7) \rightarrow$ His) were obtained by introducing single amino acid substitution using the QuikChange Mutagenesis kit (Stratagene, La Jolla) into the $\mathrm{HbI}_{L p}$ coding region cloned into the $\mathrm{pET} 28(\mathrm{a}+)$ vector (18). The $\mathrm{HbI}_{L p}$ mutants were expressed in Escherichiacoli Bli5 cells as described (18). Dark red cell pellets were lysed and centrifuged to separate the soluble from the insoluble fractions. The soluble fraction was equilibrated with $\mathrm{CO}$ and purified in $\mathrm{Co}^{2+}$ affinity columns (Talon, Invitrogen) followed by size exclusion chromatography (AKTA FPLC, Amersham Biosciences) (9). The purified $\mathrm{HbI}_{L P} \mathrm{Phe}(\mathrm{B} 10) \rightarrow$ Tyr showed UVvisible spectra typical of an oxyHbII ${ }_{L P}$. Met-aquo and $\mathrm{CO}$ $\mathrm{HbI}_{L P} \mathrm{Phe}(\mathrm{B} 10) \rightarrow$ Tyr derivatives were obtained in a similar manner as the $\mathrm{HbII}_{L P}$ complexes (18).

$\mathrm{HbII}_{L p}$ Sequence Analysis-Amino acid sequences were obtained from the NCBI protein sequence data base. The accession numbers for L. pectinata hemoglobins are HbI AAG01380, HbII AAO89499, and HbIII AAB28352. Data base searches for sequences with high sequence similarity was performed using the $\mathrm{HbII}_{L P}$ sequence and PSI-BLAST (19). Multiple sequence alignments were performed with ClustalW (20). Sequence alignments were used to assess the variation at specific positions and the resulting differences in the overall structure and distal heme cavity.

Crystallization and Data Collection- $-\mathrm{HbII}_{L P}$ was crystallized as previously reported (21). In brief, lyophilized $\mathrm{HbII}_{L P}$ was dissolved in $50 \mathrm{~mm}$ Bis Tris propane $\mathrm{pH} 7.0$ buffer, $0.5 \mathrm{~mm}$ EDTA in a final concentration of $30 \mathrm{mg} / \mathrm{ml}$. The crystals were grown by the counter-diffusion technique with a three-chamber configuration (22) using ammonium sulfate as precipitant. X-ray diffraction intensity data were collected at the BM-16 station of the European Synchrotron Radiation Facility (ESRF) using a $0.97-\AA$ wavelength in a Mar CCD-165 detector. Data were indexed, integrated, and scaled with HKL2000 suite (23) at a resolution limit of $1.93 \AA$.

Structure Solution and Refinement-The structure of $\mathrm{HbII}_{L P}$ was solved by molecular replacement methods as reported in Ref. 21. In brief, coordinates from $\mathrm{HbI}_{L p}$ (PDB code 1EBT) without the water molecule present in the distal position of the 


\section{L. pectinata Hbll Structure}

\section{TABLE 1}

Data collection and refinement statistics of $\mathrm{Hbll}_{L p}-\mathrm{O}_{2}$ structure

Statistical values for the highest resolution shell, 1.96-1.93 A for data collection and $1.98-1.93 \AA$ for refinement, are given in parentheses.

\begin{tabular}{|c|c|}
\hline $\begin{array}{l}\text { Data collection } \\
\text { Wavelength }(\AA) \\
\text { Temperature }(\mathrm{K}) \\
\text { Space group } \\
a=b, c(\AA) \\
\alpha, \beta, \gamma\left(\left(^{\circ}\right)\right. \\
\text { Monomers per asymmetric unit } \\
\text { Resolution }(\AA) \\
\text { No. of observed reflections } \\
\text { Redundancy } \\
\text { Completeness }(\%) \\
R_{\text {merge }}(\%) \\
\text { Average } I / \sigma(I I)\end{array}$ & $\begin{array}{c}0.977 \\
100 \\
\mathrm{P} 4_{2} 2_{1} 2 \\
73.92,152.35 \\
90 \\
2 \\
20.0-1.93 \\
338,327 \\
10.5(10.6) \\
99.6(100.0) \\
5.0(33.6) \\
40.0(7.0)\end{array}$ \\
\hline $\begin{array}{l}\text { Refinement } \\
R \text { value (\%) } \\
R_{\text {free value }(\%)} \\
\text { No. of reflections in working set } \\
\text { No. of reflections in test set } \\
\text { No. of solvent molecules } \\
\text { Average } B \text { factor }(\AA 2) \\
\text { Root mean square deviations } \\
\text { bond length }(\AA) \\
\text { Root mean square deviations } \\
\text { bond angles }\left(^{\circ}\right)\end{array}$ & $\begin{array}{c}16.5(17.5) \\
19.3(22.5) \\
30,675(2158) \\
1,643(137) \\
283 \\
30.42 \\
0.013 \\
\\
1.841\end{array}$ \\
\hline $\begin{array}{l}\text { Ramachandran plot } \\
\text { Most favored regions (\%) } \\
\text { Allowed regions (\%) } \\
\text { General allowed regions (\%) } \\
\text { Disallowed regions (\%) }\end{array}$ & $\begin{array}{r}94.8 \\
5.2 \\
0.0 \\
0.0\end{array}$ \\
\hline
\end{tabular}

heme iron were used as a search model and the molecular replacement solution was found using the CNS suite (24). Refinement was conducted using CNS and REFMAC5 software from CCP4 (25). After several cycles of restrained refinement, manual model building against the electron density maps was conducted with the program COOT (26). Once all the residues were replaced by the $\mathrm{HbII}_{L P}$ sequence, the $R$-factor and $R$-free decreased to 0.30 and 0.36 , respectively. Additional refinement was carried out with REFMAC5 using the TLS parameters (27). The inclusion of TLS parameters in the refinement process improved the $R$-factor and $R$-free to a final value of 0.17 and 0.19 , respectively. Water molecules were placed in electron density difference maps using the ARP/wARP version 5.0 program from the CCP4 suite. All the structures were checked using the refinement with MolProbity (28), and before deposition using PROCHECK (29). Details on data collection and structure refinement are summarized in Table 1 . The secondary structure was tested with iMolTalk (30), whereas $\beta$-turn geometry was calculated using the program PROMOTIF version 2.0 (31). Superposition and root mean square deviations of the structures were performed using the CCP4 program LSQKAB (32). Protein interfaces in the crystal were characterized using the PISA server (33). Distances between amino acids were calculated using the program CONTACT from CCP4 (25). The accessible surface areas values were computed with NACCESS (34) with a probe radius of $1.4 \AA$ and a slice width of $0.05 \AA$. Protein cavities were computed using the CASTp server (35). The coordinates and structure factors of L. pectinata $\mathrm{HbII}$ were deposited at the RCSB PDB with entry code 2OLP.

Potassium Ferricyanide Titration and Resonance Raman Spectroscopy-Deoxyhemoglobin was obtained by adding sodium dithionite to the purified protein samples, followed by a

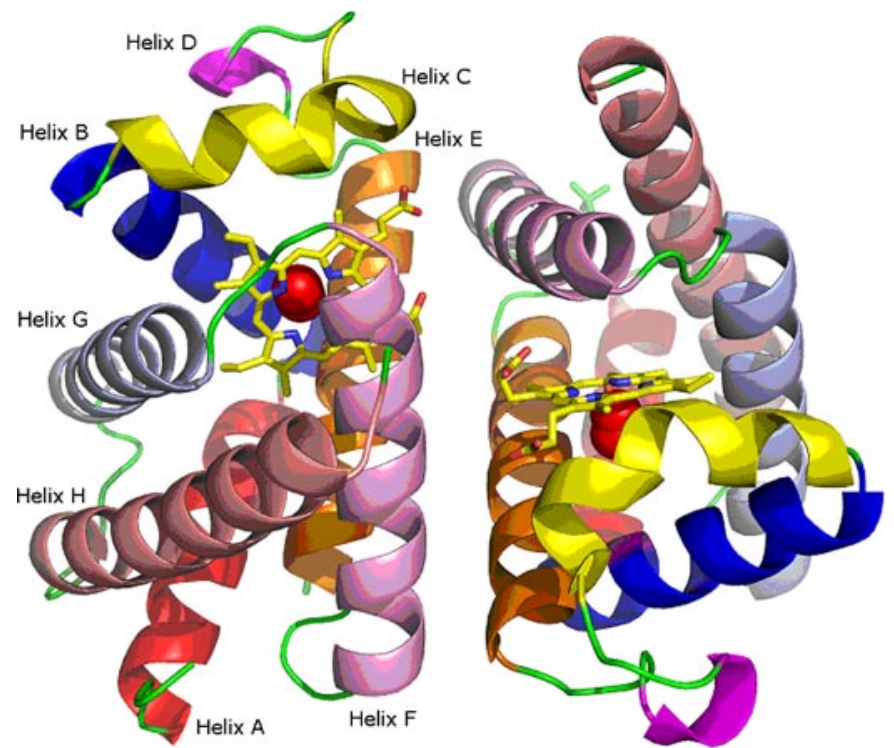

FIGURE 1. Structure of the Hbll dimer from $L$. pectinata. Each helix, $A$ to $H$, is labeled and identified by the colors: red, blue, yellow, magenta, orange, pink, light blue, and salmon, respectively.

purification step in a Hi-Trap desalting column (FPLC, GE Healthcare). Oxyhemoglobin complexes were obtained by flushing the deoxy derivatives with oxygen. The initial concentration for the oxyHb $\mathrm{H}_{L P}$ species was $3.40 \mu \mathrm{M}$, at $\mathrm{pH} 7.5$. The titration of $\operatorname{oxyHbI}_{L P}$ was initiated with the addition of $15-\mu \mathrm{l}$ aliquots of a $10 \%$ potassium ferricyanide solution (2) up to a total volume of $150 \mu$ l to obtain the met-aquo $\mathrm{HbI}_{L P}$. Full oxidation of $\mathrm{HbII}_{L P}$ and the $\mathrm{HbI}_{L P} \mathrm{Phe}(\mathrm{B} 10) \rightarrow$ Tyr mutant proteins required a decrease of $\mathrm{pH}$ from 7.5 to 5.0 , because the above conditions were not adequate. The resonance Raman measurements were made by focusing the output of a krypton ion laser at $413.1 \mathrm{~nm}$ (Spectra Physics) to a $\sim 30-\mu \mathrm{m}$ spot on a rotating cell to prevent photodamaging. The laser power was set at 10 milliwatts using a CCD back-illuminated detector $(800 \times 2000$ pixels $)$ coupled to a modified Spex 1401 centered at $410 \mathrm{~nm}$. Three spectra were collected, each composed of 60 accumulations of $10 \mathrm{~s}$. Hemoglobin concentration was $\sim 100 \mu \mathrm{M}$.

\section{RESULTS}

$\mathrm{HbII}_{L p}$ Structure and Sequence Analysis-The $\mathrm{HbII}_{L P}$ crystallizes in space group $\mathrm{P}_{2} 2_{1} 2$, and diffracts $\mathrm{X}$-rays with a resolution better than $2.0 \AA$, having unit cell parameters $a=b=$ $73.92 \AA$ and $c=152.35 \AA$, and two molecules forming a dimer in the asymmetric unit and a solvent content of $61 \%$ per volume. All the residues are placed in the most favorable region of the Ramachandran plot. $\mathrm{HbII}_{L P}$ shows the characteristic globin fold with six $\alpha$-helices surrounding the central heme pocket, and two minor helical segments between B and E helices (Fig. 1). The distance between the iron atoms in the dimer is $17.8 \AA$, and the plane orientation of the porphyrin ring is almost perpendicular. This short distance between the heme groups is a characteristic feature of the EF-dimers in other types of molluscan hemoglobin (36). The dimer interface includes 25 residues of each monomer and covers a surface of $845 \AA^{2}$. At the interface, four hydrogen bonds, namely, $\operatorname{Lys}^{95 \mathrm{~B}}-\operatorname{Ser}^{46 \mathrm{~A}}(2.77 \AA)$, 
HbII L.pectinata HBIII L.pectinata BbI L. pectinata HbI s.inaequivalvis HbIIA s.inaequivalvis HbIIB S.inaequivalvis Hb domainI A.suum

HbII L.pectinata HBIII L.pectinata abI L,pectinata tbI s.inaequivalvis HbIIA S.inaequivalvis HbIIB S,inaequivalvi thb domainI A.suum

HbII L.pectinata HBII L.pectinata HbI L.pectinata HbI s, inaequivalvis HbIIA S.inaequivalvi HbIIB S.inaequivalvis Hb domainI A.suum

HbII L.pectinata HBIII L.pectinata HbI L.pectinata HbI s.inaequivalvis HbIIA S.inaequivalvis HbIIB S.inaequivalvis Hb domainI A.suum

FIGURE 2. Multiple sequence alignment of the three types of hemoglobin from L. pectinata, the bivalve mollusk S. inaequivalvis, and domain one of the nematode A. suum hemoglobin. The corresponding helices as predicted by the program suite iMoltalk applying the STRIDE method are labeled (red squares). Conserved residues are shaded in cyan and residues at position B10 (Tyr ${ }^{30}$ in L. pectinata), E7 (GIn ${ }^{65}$ in $L$. pectinata), Lys ${ }^{92}$ and $\operatorname{Arg}^{100}$ (L. pectinata) are shaded in yellow. The gaps are labeled in green.
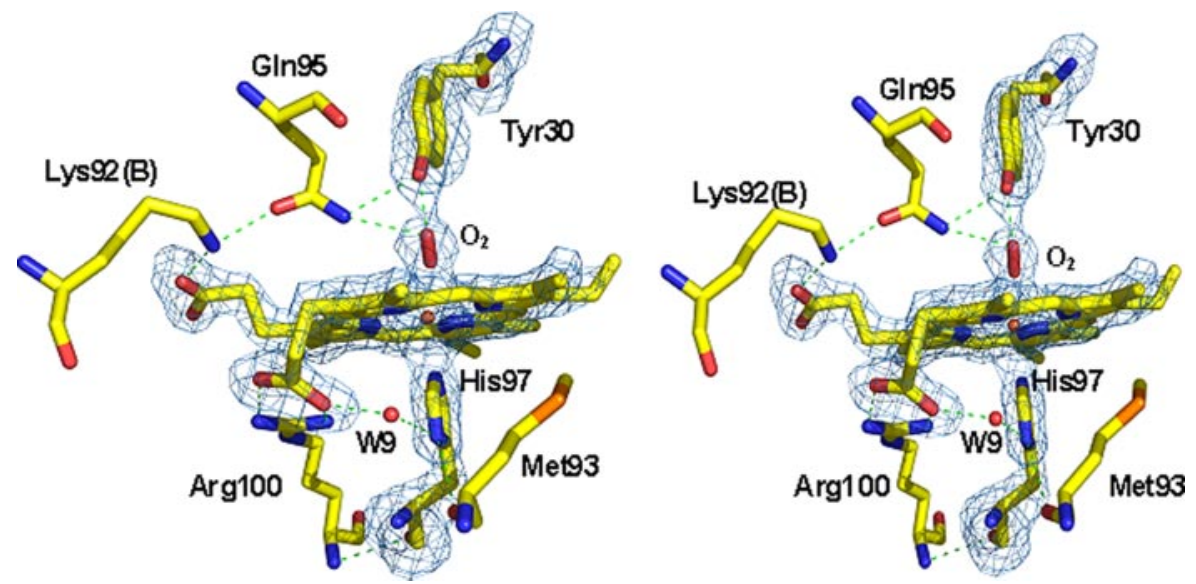

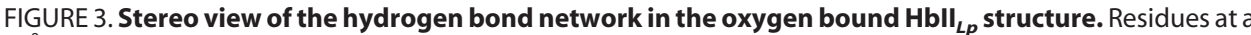
5 -Å distance cut-off are shown. The omit map (contoured at $3 \sigma$ ) and bond interactions are shown in blue and green lines, respectively. Distances between residues are shown in Table 2.

Lys $^{95 \mathrm{~A}}-\operatorname{Ser}^{46 \mathrm{~B}}(2.98 \AA)$, Lys $^{92 \mathrm{~B}}-\mathrm{Gln}^{65 \mathrm{~A}}\left(2.73 \AA\right.$ ) , and Lys ${ }^{92 \mathrm{~A}}$ $\operatorname{Gln}^{65 \mathrm{~B}}(2.66 \AA)$, and one salt bridge $\mathrm{Asp}^{82 \mathrm{~B}}-\mathrm{Lys}^{63 \mathrm{~A}}(3.05 \AA)$ are found. It is noteworthy that the $\mathrm{HbII}_{L P}$ structure confirms the existence of one aspartate in position 84 and an acetyl group in the $\mathrm{N}$ terminus as previously suggested by comparison of matrix-assisted laser desorption ionization-mass spectrometry results and the cDNA-derived amino acid sequences (8).

The sequence alignments of the hemoglobins of $L$. pectinata, S. inaequivalvis, and A. suum are shown in Fig. 2. The multiple alignment has three gaps: one between the $\mathrm{C}$ and $\mathrm{D}$ helices, a second one within the G helix, and the third gap after the $G$ helix. The $\mathrm{B} 10$ residue varies from a Phe in $\mathrm{HbI}_{L P}$, Tyr in $\mathrm{HbII}_{L P}$, $\mathrm{HbIII}_{L P}$, and $\mathrm{Hb}_{A s c}$ to a Met in the three types of hemoglobins from S. inaequivalvis, whereas the E7 position contains a His the coelomic fluid erythrocytes from the bivalve mollusk $S$. inaequivalvis (38) and they have been proposed to play an important role in the allosteric behavior of hemoglobin $\mathrm{Hb}_{\mathrm{I}, S i}$ (39).

The major differences between chains $\mathrm{A}$ and $\mathrm{B}$ in the L. pectinata $\mathrm{HbII}$ dimer are found in the $\beta$-turn formed by residues Gly $^{122}-$ Gly $^{123}-$ Leu $^{124}-\mathrm{Thr}^{125}$ with a maximum root mean square deviation of 3.4 $\AA$. The $\beta$-turn is a type I in chain $\mathrm{A}$, and a type IV in chain $B$. This difference in conformation arises from a difference in the environment, the $\beta$-turn has several contacts with the symmetry related molecule in chain A, whereas in chain $\mathrm{B}$, it is exposed to the solvent. This $\beta$-turn is also one of the major differences between the $\mathrm{HbII}_{L P}$ and $\mathrm{HbI}_{L P}$ structures. 
TABLE 2

Heme contacts in $\mathrm{Hbll}_{L p}-\mathrm{O}_{2}$ structure

\begin{tabular}{|c|c|c|c|c|c|}
\hline \multirow{2}{*}{ Residue 1} & \multirow{2}{*}{ Atom } & \multirow{2}{*}{ Residue 2} & \multirow{2}{*}{ Atom } & \multicolumn{2}{|c|}{ Distance $(\AA)$} \\
\hline & & & & Chain A & Chain B \\
\hline \multirow[t]{14}{*}{ HEM } & \multirow[t]{2}{*}{ O1A } & $\operatorname{Arg}^{100}$ & $\mathrm{NH}_{2}$ & 2.71 & 2.52 \\
\hline & & W6/W7 & $\mathrm{O}^{2}$ & 2.62 & 2.57 \\
\hline & \multirow[t]{3}{*}{$\mathrm{O} 2 \mathrm{~A}$} & $\operatorname{Arg}^{100}$ & NH1 & 2.98 & 2.88 \\
\hline & & $\mathrm{Arg}^{100}$ & $\mathrm{NH}_{2}$ & 3.47 & 3.34 \\
\hline & & W9/W2 & $\mathrm{O}$ & 2.59 & 2.63 \\
\hline & \multirow[t]{2}{*}{ O1D } & Lys $^{92 a}$ & NZ & 2.63 & 2.72 \\
\hline & & W43/W5 & $\mathrm{O}$ & 2.64 & 2.67 \\
\hline & \multirow[t]{4}{*}{$\mathrm{O} 2 \mathrm{D}$} & W8/W3 & $\mathrm{O}$ & 2.62 & 2.66 \\
\hline & & W34/W5 & $\mathrm{O}$ & 2.59 & 3.41 \\
\hline & & W43/33 & $\mathrm{O}$ & 3.42 & 2.62 \\
\hline & & W57/139 & $\mathrm{O}$ & 2.96 & 2.98 \\
\hline & \multirow[t]{3}{*}{$\mathrm{Fe}$} & $\mathrm{His}^{97}$ & NE2 & 2.08 & 2.04 \\
\hline & & Oxy & O1 & 2.94 & 2.85 \\
\hline & & Oxy & $\mathrm{O} 2$ & 2.11 & 1.69 \\
\hline \multirow[t]{3}{*}{$\mathrm{Tyr}^{30}$} & \multirow[t]{3}{*}{$\mathrm{OH}$} & $G \ln 65$ & NE2 & 3.00 & 3.07 \\
\hline & & Oxy & $\mathrm{O} 1$ & 1.94 & 1.78 \\
\hline & & Oxy & $\mathrm{O} 2$ & 2.99 & 2.95 \\
\hline \multirow[t]{2}{*}{$\mathrm{His}^{97}$} & \multirow[t]{2}{*}{ ND1 } & Met $^{93}$ & $\mathrm{O}$ & 2.98 & 2.79 \\
\hline & & W9/W2 & $\mathrm{O}$ & 3.45 & 3.41 \\
\hline \multirow[t]{4}{*}{ Q65A } & OE1 & Lys92 ${ }^{a}$ & NZ & 2.73 & 2.66 \\
\hline & \multirow[t]{3}{*}{ NE2 } & $\mathrm{Tyr}^{30}$ & $\mathrm{OH}$ & 3.00 & 3.07 \\
\hline & & Oxy & O1 & 3.02 & 3.04 \\
\hline & & Oxy & $\mathrm{O} 2$ & 3.43 & 3.51 \\
\hline
\end{tabular}

${ }^{a}$ Marked contacts are inter-polypeptides chains.

HbII $_{L p}$ Distal and Proximal Heme Pocket-Fig. 3 shows the structure and the hydrogen bonding network of the oxy $\mathrm{HbII}_{L P}$ proximal and distal sites. The porphyrin ring adopts a planar configuration with the iron atom in the plane, and the average distance of the pyrrolic nitrogens to the iron is $2.06 \AA$. The dioxygen forms an angle of $123^{\circ}$ with the iron atom in chain $\mathrm{A}$, and $162^{\circ}$ in chain $B$. The heme pocket in chain B is slightly smaller than in chain $\mathrm{A}$ and the distance between the $\mathrm{OH}$ of the distal tyrosine and the iron atom is shorter $(4.84 \AA$ in chain $\mathrm{A}$ and $4.53 \AA$ in chain $B$, but the differences in the volume size of the heme cavity are $912.6 \AA^{3}$ in chain A and $831.9 \AA^{3}$ in chain B) might arise from small differences in the position of the atoms as a consequence of the average coordinates position. In the $\mathrm{HbII}_{L P}$ heme cavity most of the aromatic residues are conserved when compared with $\mathrm{HbI}_{L P}$ (for instance, $\operatorname{Trp}(\mathrm{A} 11)$, Phe(B9), Phe(C7), Phe(CD5), Phe(E11), and Trp(H8)), except Tyr(B10), $\operatorname{Tyr}(\mathrm{G} 8)$, and $\operatorname{Tyr}(\mathrm{G} 14)$, which are replaced by phenylalanine in the $\mathrm{HbI}_{L P}$ sequence, and Phe(E18) that is replaced by tryptophan. Although the $\mathrm{HbII}_{L P}$ proximal heme pocket is mainly hydrophobic, it contains one buried water molecule $\left(\mathrm{W}^{9}\right)$. This water molecule forms a hydrogen bond with the heme propionate group $(\mathrm{O} 2 \mathrm{~A})$ within a distance of $2.59 \AA$ and with $\mathrm{His}^{97}$ (ND1) within a distance of $3.45 \AA$ (Table 2). It is also part of the water network in the interface of the $\mathrm{HbII}_{L P}$ dimer. A water molecule is also present in the heme pocket of the $\mathrm{HbI}_{L P}$ as part of an identical hydrogen network.

When $\mathrm{HbI}_{L P}$ and $\mathrm{HbII}_{L P}$ are superimposed using the heme group as a reference, the $\mathrm{HbI}_{L P}$ as well as the proximal histidine show a displacement of $\sim 1 \AA$. The orientation of the proximal $\mathrm{His}^{97}(\mathrm{~F} 15)$ is roughly perpendicular to the heme plane and the average distance between the His ${ }^{97}$ (NE2) atom and the iron atom is $2.06 \AA$, which is a slightly shorter distance when compared with the sulfide (PDB code $1 \mathrm{MOH}$ ), cyanide (PDB codes $1 \mathrm{ETB}$ and $1 \mathrm{~B} 0 \mathrm{~B}$ ), and water-bound $\mathrm{HbI}_{L P}$, where the distances range from 2.13 to $2.31 \AA$. It has been suggested that within the various kinds of hemoglobin and myoglobin a hydrogen bond

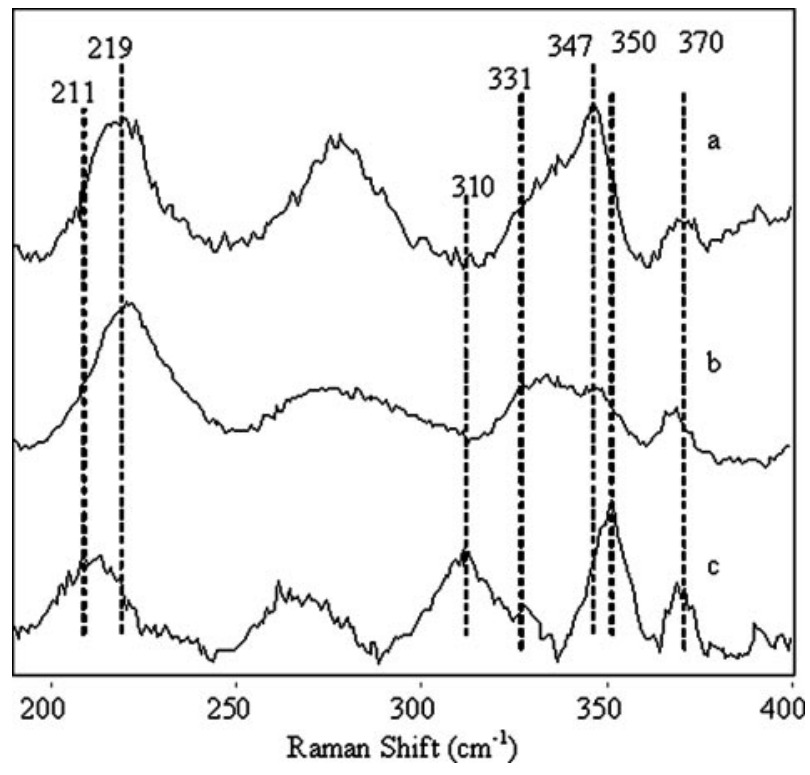

FIGURE 4. Resonance Raman spectra of deoxy samples of (a) $\mathrm{Hbl}_{L p}$, (b) $\mathrm{HbI}_{L p} \mathrm{Phe}(\mathrm{B} 10) \rightarrow \mathrm{Tyr}$, and (c) Hbll $\mathrm{Hp}_{\text {p }}$ showing the Fe-His stretching mode and trans-effect of the proximal His.

between the proximal histidine His(F8) and the side chain of a residue next to it modulates the strength of the His-Fe bond, regulating the ligand affinity $(37,40)$. In $\mathrm{HbII}_{L P}$, His(F8) has two possible hydrogen bond interactions, the first one with the buried water molecule and the second one from the interaction of the carbonyl group of $\mathrm{Met}^{93}$ and the ND1 from histidine (Table 2). A similar hydrogen bond is formed between the carbonyl of $\mathrm{Met}^{93}$ and the histidine ND1 atom in $\mathrm{HbI}_{L P}$.

Heme Oxidation and Resonance Raman Spectra of Oxy Species-HbI titration with potassium ferricyanide required an additional oxidizing agent to complete oxidation to the met-aquo $\mathrm{HbI}_{L P}$ form, shifting the Söret band from $416 \mathrm{~nm}$ $\left(\right.$ oxy $\mathrm{HbI}_{L P}$ ) to a maximum at $407 \mathrm{~nm}$ (supplemental Fig. 2). A $\mathrm{pH}$-dependent titration for oxyHbII $\mathrm{I}_{L P}$ and the oxyHbI $\mathrm{I}_{L P^{-}}$ Phe(B10) $\rightarrow$ Tyr mutant required a decrease in $\mathrm{pH}$ from 7.5 to 5.5 to completely change the Söret band from 414 to $403 \mathrm{~nm}$, a characteristic of the met-aquo $\mathrm{HbII}_{L P}$ species. This result suggests that Tyr in the $\mathrm{B} 10$ position is responsible for the $\mathrm{pH}$ oxidation control of oxyHbII ${ }_{L P}$ and the oxyHbI ${ }_{L P} \mathrm{Phe}(\mathrm{B} 10) \rightarrow$ Tyr mutant. Similarly, Fig. 4 compares the low frequency resonance Raman spectra of ferrous deoxygenated recombinant $\mathrm{HbI}_{L P}, \mathrm{HbI}_{L P} \mathrm{Phe}(\mathrm{B} 10) \rightarrow \mathrm{Tyr}$, and $\mathrm{HbII}_{L P}$, which provides information on the Fe-His stretching mode $\left(v_{\mathrm{FeN}}\right)$ and the trans-effect of the proximal histidine on the $\mathrm{Fe}-\mathrm{O}_{2}$ mode. The vibrational frequencies (Fig. 4, $a$ and $b$ ) for $\mathrm{HbI}_{L P}$ and the $\mathrm{HbI}_{L P} \mathrm{Phe}(\mathrm{B} 10) \rightarrow$ Tyr mutant are located at $219 \mathrm{~cm}^{-1}$, similar to the myoglobin spectrum. However, for $\mathrm{HbII}_{L P}$ the $v_{\mathrm{FeN}}$ is present at a lower frequency, $211 \mathrm{~cm}^{-1}$ (Fig. $4 c$ ), suggesting that the factors controlling the strength of the $\mathrm{Fe}-\mathrm{N}$ bond are not the same for both sets of hemoproteins. Normal mode assignments were based on the presence or absence of a particular frequency on the spectra for the $\mathrm{HbI}_{L P}$-ligand complexes and compared with the values reported in the literature $(17,41)$. The $v_{\mathrm{FeN}}$ for hemoglobin and myoglobin has been found in the resonance Raman spectra between the 217 and $244 \mathrm{~cm}^{-1}$ regions $(17,41$, 42). The spectra also show a band at $370 \mathrm{~cm}^{-1}$, which has pre- 


\section{L. pectinata Hbll Structure}

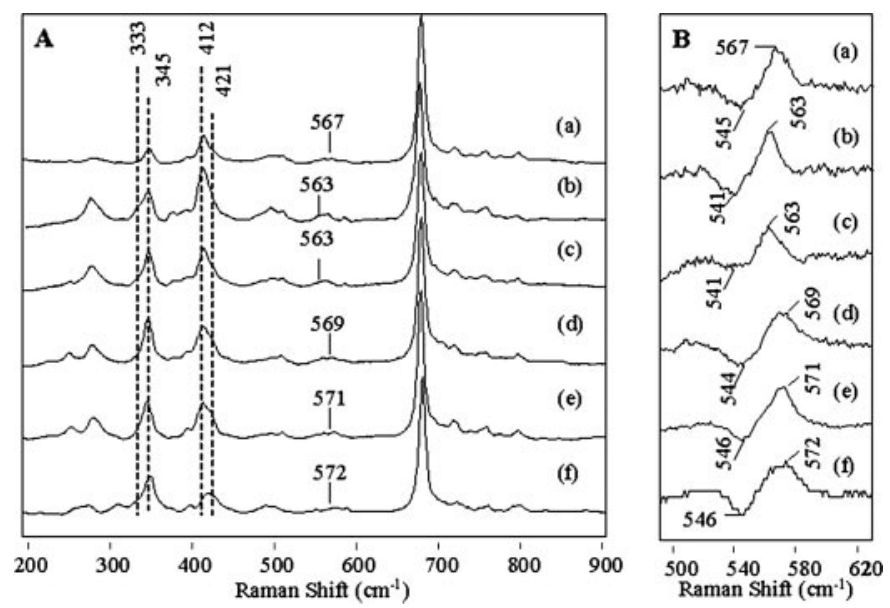

FIGURE 5. $A$, resonance Raman spectra of oxy species $\mathrm{Hbll}_{L p} \mathrm{Hbl}_{L p}$ and $\mathrm{Hbl}_{L p}$ mutants. $B$, oxygen isotopic shift for the $\mathrm{Fe}-\mathrm{O}_{2}$ normal mode vibration of the oxyHbl| $L_{L p}$, oxyHbl $_{L p}$ and oxyHb| $\mathrm{I}_{L p}$ mutants.

viously been attributed to the $\mathrm{C}_{\beta}-\mathrm{C}_{\mathrm{c}}-\mathrm{C}_{\mathrm{d}}$ bending motion of the peripheral propionate heme substituents in $\mathrm{HbI}_{L P}$. The spectra for $\mathrm{HbI}_{L P}$ and $\mathrm{HbI}_{L P} \mathrm{Phe}(\mathrm{B} 10) \rightarrow$ Tyr also show the $v_{8}$ band at $347 \mathrm{~cm}^{-1}$. This is characteristic of the combination of the metal-pyrrole stretch and the in-plane substituent bend, and a shoulder at $331 \mathrm{~cm}^{-1}$ that has been assigned to the out-of-plane pyrrole-tilting mode. In contrast, in $\mathrm{HbII}_{L P}$ the spectral bands have been displaced to 350 and $310 \mathrm{~cm}^{-1}$, respectively.

Fig. $5 \mathrm{~A}$ shows the vinyl region and the $\mathrm{Fe}-\mathrm{O}_{2}$ vibration for $\mathrm{HbII}_{L P}$, recombinant $\mathrm{HbI}_{L P}$ and a series of $\mathrm{HbI}_{L P}$ mutants. Some differences in their vibrational modes are observed as function of the polarity of the heme pocket and oxygen isotopic substitution. For example, the recombinant $\mathrm{HbI}_{L P}$ (Fig. 5A, a) shows a relatively strong band at $412 \mathrm{~cm}^{-1}$ with a small shoulder at $421 \mathrm{~cm}^{-1}$. The former corresponds to an in-plane vinylbending mode $\left(\delta \mathrm{C}_{\mathrm{b}} \mathrm{C}_{\alpha} \mathrm{C}_{\beta}\right.$-vinyl), whereas the latter is attributed to either a contribution from both vinyls or the same vinyl reflecting heterogeneity among heme subunits. Only small intensity changes are observed as a function of amino acid substitution. Similarly, the $v_{8}$ band is found at $345 \mathrm{~cm}^{-1}$, which is invariant among the different hemeprotein derivatives. The shoulder of the out-of-plane pyrrole-tilting mode at $333 \mathrm{~cm}^{-1}$ is almost absent in the samples. Fig. $5 \mathrm{~B}$ shows the ${ }^{16} \mathrm{O}_{2}-{ }^{18} \mathrm{O}_{2}$ isotope difference spectra, where the $\mathrm{Fe}-\mathrm{O}_{2}$ stretching mode of the heme $\mathrm{O}_{2}$ moiety presents a significant frequency change as a function of the heme pocket amino acids. Thus, the spectrum of recombinant $\mathrm{HbI}_{L P}$ (Fig. $5 B, a$ ) shows a band at $567 \mathrm{~cm}^{-1}$, which was previously attributed to the $\mathrm{Fe}-\mathrm{O}_{2}$ stretching mode, and in this work, has been confirmed by the oxygen isotopic substitution. Changing the residue at the $\mathrm{E} 7$ position in the $\mathrm{HbI}_{L P} \mathrm{Gln}(\mathrm{E} 7) \rightarrow \mathrm{Val}$ and $\mathrm{HbI}_{L P} \mathrm{Gln}(\mathrm{E} 7) \rightarrow$ Asn mutants (Fig. $5 B, b$ and $c$ ) produced a decrease in the stretching mode to $563 \mathrm{~cm}^{-1}$, whereas changing the residue at the E7 position with the $\mathrm{HbI}_{L P} \mathrm{Gln}(\mathrm{E} 7) \rightarrow$ His or at the $\mathrm{B} 10$ position in $\mathrm{HbI}_{L P} \mathrm{Phe}(\mathrm{B} 10) \rightarrow$ Tyr mutants (Fig. $5 B, d$ and $e$ ) increased the frequency of the Fe-O normal mode to 569 and 572 $\mathrm{cm}^{-1}$, respectively. For the wild-type $\mathrm{HbII}_{L P}$ this frequency is present at $573 \mathrm{~cm}^{-1}$ (Fig. $5 B, f$ ), suggesting that the oxygen in the heme $\mathrm{O}_{2}$ moiety is strongly hydrogen bonded to the distal pocket $\operatorname{Tyr}^{30}(\mathrm{~B} 10)$ and $\mathrm{Gln}{ }^{65}(\mathrm{E} 7)$, in good agreement with the proposed $x$-ray structure.

\section{DISCUSSION}

The crystal structure of oxyHbII from L. pectinata has been solved and it shows relevant differences when compared with the ferric $\mathrm{HbI}_{L P}$ sequence and structure (the oxyHbI $\mathrm{I}_{L P}$ structure has not been resolved yet). The overall hemoglobin fold is conserved in these clam proteins. Some important differences between them are found in the additional residues in the sequence of $\mathrm{HbII}_{L P}$ and the flexible $\beta$-turn formed by the GGLT residues. The heme cavity is conserved between the $\mathrm{HbI}_{L P}$ and $\mathrm{HbII}_{L P}$ forms, with the exception of the $\mathrm{B} 10$ position, which is occupied by Phe and Tyr, respectively. A significant displacement of the heme group is observed in the least square superimposition of both types of hemoglobins. The heme group is buried farther in $\mathrm{HbII}_{L P}$ than in $\mathrm{HbI}_{L P}$ because of the minor steric hindrance of the $\mathrm{Met}^{93}$ and $\mathrm{Phe}^{76}$ residues that are replaced by $\mathrm{Phe}^{92}$ and $\operatorname{Trp}^{75}$, respectively. Oxygen is tightly bound to the $\mathrm{HbII}_{L P}$ heme distal site through simultaneous hydrogen bonds with $\operatorname{Tyr}(\mathrm{B} 10)$ and $\mathrm{Gln}(\mathrm{E} 7)$ (Fig. 3). This last pair of amino acids has been proposed to stabilize the oxygenated form of $\mathrm{HbII}_{L P}$ by means of strong and weak hydrogen bonds, respectively $(37,40) . \mathrm{Hb}_{\text {Asc }}$ also has a $\operatorname{Tyr}(\mathrm{B} 10)$ and a $\mathrm{Gln}(\mathrm{E} 7)$, and a high oxygen affinity and unusually slow off rate for oxygen dissociation $(15,41)$. The $\mathrm{Hb}_{A s c}$ crystal structure (PDB 1ASH) shows that the distance between the iron to oxygen $\mathrm{O} 1$ is $1.90 \AA$, and between $\operatorname{Tyr}(\mathrm{B} 10)(\mathrm{OH})$ to $\mathrm{O}_{2}$ is $2.73 \AA$ (40). Table 2 presents several distances between the oxygen heme moiety and the amino acids in the distal pocket of $\mathrm{HbII}_{L P}$. For example, the iron to oxygen $\mathrm{O} 1$ is $2.94 \AA$, and from $\operatorname{Tyr}(\mathrm{B} 10)(\mathrm{OH})$ to $\mathrm{O}_{2}$ is $2.99 \AA$. These longer distances are rather similar to those found in the structure of $M$. tuberculosis hemoglobin $\mathrm{N}$ (12). The orientation of the dioxygen bound to the heme plane is $110^{\circ}$, similar to the value found in the $\mathrm{HbII}_{L P}$ structure, but in this case, the oxygen molecule is pointing toward the $\operatorname{Tyr}(\mathrm{B} 10)(\mathrm{OH})$ group. A CASTp calculation resulted in an average volume of $1000 \AA^{3}$ for the heme cavity in $M$. tuberculosis hemoglobin, which is slightly larger than the average size of $872 \AA^{3}$ for $\mathrm{HbII}_{L P}$. Similarly, a large cavity volume was observed in the ferric derivative of the $\mathrm{Mb}$ triple mutant (L29F/H64Q/V68F), Mb, and $\mathrm{HbI}_{L P}$. The crystal structure reveals the existence of a much greater heme freedom and larger distal cavity volume in $\mathrm{HbI}_{L P}$ than sperm whale $\mathrm{Mb}$, in both the $\mathrm{H}_{2} \mathrm{~S}$ bound and unbound to the heme group, because of the lack of hydrogen bonding between the heme propionate groups and nearby amino acid residues (43). This dynamic behavior is absent in $\mathrm{HbII}_{L P}$, where the heme group is firmly anchored in place.

Cooperativity and Allosteric Effects-In contrast to a remarkably conserved tetrameric arrangement in vertebrate hemoglobins, invertebrate hemoglobins show a large diversity in quaternary structures (36). The aggregation state of the hemoglobin plays a central role in their cooperative behavior. Hemoglobins from $L$. pectinata show that $\mathrm{HbI}_{L P}$ is a monomer in all of the conditions assayed, whereas $\mathrm{HbII}_{L P}$ and $\mathrm{HbIII}_{L P}$ behave as apparent monomers at low concentrations and aggregates at higher concentrations (2). $\mathrm{Lys}^{92}$ of $\mathrm{HbII}_{L P}$ may play an impor- 


\section{L. pectinata Hbll Structure}

tant role in dimer stability, because a Thr that disrupts the possibility to form a bond between chains replaces this residue in the $\mathrm{HbI}_{L P}$ sequence. Lys ${ }^{92}$ is conserved in $\mathrm{HbIII}_{L P}$ opening up the possibility to form a heterodimer as occurs in S. inaequivalvis hemoglobins. The oligomeric hemoglobins from $S$. inaequivalvis show cooperativity in oxygen binding. However, a Hill coefficient of 1.1 was obtained for the oxygen binding measurement of $\mathrm{HbII}_{L P}$, regardless of the aggregation state $(2,3)$. Several mutant forms of the $\mathrm{Hb}_{\mathrm{I}, S i}$ dimer have structurally characterized, suggesting that two residues play an important allosteric role. First, $\mathrm{Phe}^{97}$ (F3) is packed tightly in the heme pocket in the deoxy $\mathrm{Hb}_{\mathrm{I}, S i}$ state, and exposed to the dimer interface upon ligand binding (44). The displacement of the bulky $\mathrm{Phe}^{97}$ side chain to the dimer interface displaces several water molecules leaving the interface with less water and a poorer ordered water network. A similar behavior has been described for the heterotetramer of $\mathrm{Hb}_{\mathrm{IIA}, S i}$ and $\mathrm{Hb}_{\mathrm{IIB}, S i}$ in which mutation of the Phe ${ }^{97}$ to leucine provokes a loss of cooperativity (44). Another residue playing a determinant role is $\mathrm{Thr}^{72}$, and both $\mathrm{Phe}^{97}$ and $\mathrm{Thr}^{72}$ are replaced in $\mathrm{HbII}_{L p}$ by methionine and valine, respectively.

The superpositions of the $\mathrm{HbII}_{L p}$ structure to the oxygen bound (PDB code $3 \mathrm{SDH}$ ) and unbound (PDB code 4SDH) hemoglobin states of the $S$. inaequivalvis show that $\mathrm{Asn}^{100}$ in these hemoglobins is replaced by $\mathrm{Leu}^{96}$ in $\mathrm{HbII}_{L p}$, leading to the loss of a strong hydrogen bond between $\mathrm{Asn}^{100}$ and the heme propionate group. Moreover this propionate moiety of the heme group in S. inaequivalvis shows an important displacement between the oxygen-bound and unbound forms. In particular, the orientation of the unbound form is equivalent to the orientation of the propionate in the oxyHbII $\mathrm{Lp}_{L}$ structure. The interaction with the nearest residues is the same in $\mathrm{Hb}_{S i}$, even a water molecule equivalent to the water molecule $\left(\mathrm{W}^{9}\right)$ bound to His $^{97}$ (Fig. 3) is found at a distance of $2.52 \AA$ A. Interestingly, this water molecule disappears in the oxygen-bound structure of $S$. inaequivalvis. This observation supports the hypothesis that this water molecule plays an important role in the regulation of the heme group affinity to ligands.

Geometry of the Heme-Oxygen Moiety and Hydrogen Bonding Network-The hydrogen bonding network between the heme bound oxygen and the $\mathrm{Gln}(\mathrm{E} 7)$ and $\mathrm{Tyr}(\mathrm{B} 10)$ of $\mathrm{HbII}_{L p}$ is almost identical to the active center of $\mathrm{Hb}_{A s c}$. In both cases, it has been proposed that the hydrogen bonding network is responsible for their extremely low oxygen dissociation rates $(15,41)$. Despite this analogy, the oxygen dissociation rate constant for $\mathrm{HbII}_{L p}$ and $\mathrm{Hb}_{A s c}$ shows a difference of 2 orders of magnitude $(0.11$ and $0.004 \mathrm{~s}^{-1}$, respectively). This suggests that other factors, like the $\mathrm{His}^{97}$ (F8) trans-effect and its orientation, could play an important role in determining this rate difference. The resonance Raman measurements allows a comparison between the Fe-His stretching mode of $\mathrm{Mb}, \mathrm{HbII}_{L p}$, and $\mathrm{Hb}_{A s c}$, at 220, 211, and $202 \mathrm{~cm}^{-1}$, respectively, whereas for recombinant $\mathrm{HbI}_{L p}$ and the $\mathrm{HbI}_{L p}$ Phe(B10) $\rightarrow$ Tyr mutant, the Fe-N stretching mode is characterized by a band at $219 \mathrm{~cm}^{-1}$ (Fig. 4). The FeHis normal mode falls into the group of heme proteins that have a neutral proximal histidine, characteristic of those responsible for transporting oxygen, where the proximal histidine environment differs for these three hemeproteins. The strength of the
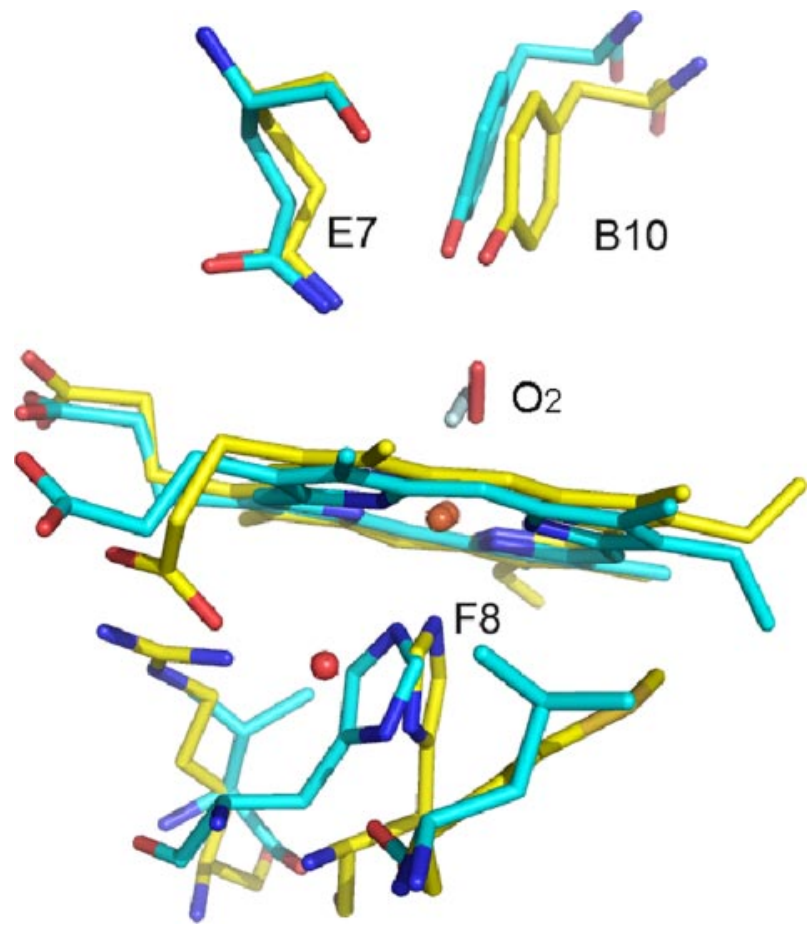

FIGURE 6. Oxygen heme moiety. Least square superposition of $\mathrm{Hbll}_{L p}$ (yellow) and $\mathrm{Hb}_{\text {Asc }}$ (cyan, PDB code $1 \mathrm{ASH}$ ). The superposition was carried out taking into account all the residues in the structure (amino acids and prosthetic group). The water molecule forming a hydrogen bond between the propionate group and $\mathrm{His}^{97}(\mathrm{~F} 8)$ in $\mathrm{Hbll}_{L p}$ is also shown. This water molecule is not present in the oxygen bound structure of $\mathrm{Hb}_{A s c}$. The oxygen molecule shows opposite orientation in both structures (the oxygen molecule in $\mathrm{Hb}_{\text {Asc }}$ is shown in clear cyan).

hydrogen bond formed by a nitrogen proton in the proximal histidine and the polarity of the environment are powerful factors for determining the Fe-His stretching frequency in the heme-histidine moiety. This hydrogen bonding network in hemoglobins and myoglobins has also been also related to ligand affinity $(37,40)$. The significant differences observed in the heme-ligand dissociation rate constants between $\mathrm{Mb}$ and $\mathrm{Hb}_{\text {Asc }}$ have mainly been attributed to the tilted orientation of the His(F8) with regard to the pyrrole rings of the heme (45). Fig. 6 shows an overlay of the oxy heme moiety of $\mathrm{Hb}_{A s c}$ and $\mathrm{HbII}_{L p}$ indicating several structural differences in the orientation of the proximal histidine, the bound oxygen, propionates, and vinyl groups. In particular, the presence of a water molecule between the propionate group of heme and His(F8) in $\mathrm{HbII}_{L p}$ suggests that the Fe-His strength and the His-Fe trans-effect may be modulated by this hydrogen bond. Furthermore, the orientation of $\mathrm{His}(\mathrm{F} 8)$, as suggested for $\mathrm{Hb}_{A s c}$, can also contribute to the observed Fe-His frequency. The combination of these factors facilitates the strength of the $\mathrm{Fe}-\mathrm{O}_{2}$ complex in the distal heme pocket. Moreover, the small distal cavity volume of $\mathrm{HbII}_{L p}$ and its hydrogen bonding network with the heme- $\mathrm{O}_{2}$ moiety is consistent with the relationship between the $\mathrm{Fe}-\mathrm{O}_{2}$ stretching mode and its oxygen dissociation rate constant $\left(k_{\text {off }}\right)$ (46). This is supported by data in Table 3, which shows a rough inverse relationship between these two properties for $\mathrm{HbII}_{L p}$, $\mathrm{HbI}_{L p}$, and several $\mathrm{HbI}_{L p}$ mutants. For example, oxyHbII $\mathrm{H}_{L p}$ and oxyHbI $_{L p}$ show Fe-O frequencies at 572 and $567 \mathrm{~cm}^{-1}$ correlated with an oxygen dissociation rate constant (2) of 0.11 and 
TABLE 3

$v \mathrm{Fe}-\mathrm{O}_{2}$ and dissociation rate constants $\left(k_{\text {off }}\right)$ for $\mathrm{Hbll}_{L p}, \mathrm{Hbl}_{L p}$, and $\mathrm{Hbl}_{L p}$ mutants

\begin{tabular}{lcc}
\hline \multicolumn{1}{c}{ Heme protein } & $\boldsymbol{v}_{\mathrm{FeO}_{2}}$ & $\boldsymbol{k}_{\text {off }}$ \\
\hline & $c m^{-1}$ & $s^{-1}$ \\
HbI (Gln(E7), Phe(B10), Phe(E11)) & 567 & $61.0^{a}$ \\
HbI ${ }_{\mathrm{r}}$ (Gln(E7), Phe(B10), Phe(E11)) & 567 & 140.0 \\
HbIGln(E7) $\rightarrow$ Val & 563 & 500.0 \\
HbIGln(E7) $\rightarrow$ Asp & 563 & 375.0 \\
HbIGln(E7) $\rightarrow$ His & 569 & 3.0 \\
HbIPhe(B10) $\rightarrow$ Tyr & 571 & 0.60 \\
HbII (Gln(E7), Tyr(B10), Phe(E11)) & 572 & $0.11^{a}$ \\
\hline${ }^{a}$ Tyr
\end{tabular}

${ }^{a}$ From Ref. 2.

$61 \mathrm{~s}^{-1}$, respectively. Similarly, $\mathrm{HbI}_{L p} \mathrm{Gln}(\mathrm{E} 7) \rightarrow$ Asp and $\mathrm{HbI}_{L p} \mathrm{Gln}(\mathrm{E} 7) \rightarrow$ Val mutants show an increase in the dissociation rate constant from $140 \mathrm{~s}^{-1}$ (for HbIr specie) to 375 and $500 \mathrm{~s}^{-1}$, whereas the Fe-O normal mode frequency decreases to $563 \mathrm{~cm}^{-1}$ (46). The faster oxygen dissociation rates suggest that the interactions of the $\mathrm{E} 7$ residue in these two mutants are much weaker than in $\mathrm{HbI}_{L p}$, thus corroborating that the absence of a hydrogen bond induces a lower Fe-O vibrational frequency. Although no dipolar interaction exists between the residues in the $\mathrm{E} 7$ position in these two mutants, the observed frequencies in the $\mathrm{HbI}_{L p}$ mutants are higher than expected probably due to multipole interactions of the three phenylalanine residues (B10, E11, and CD1) in the distal side of the heme (47). The $\mathrm{HbI}_{L p} \mathrm{Gln}(\mathrm{E} 7) \rightarrow$ His mutant induces a much stronger polar interaction between this residue and the dioxygen heme complex with a dissociation rate constant $\left(k_{\text {off }}\right)$ of $3 \mathrm{~s}^{-1}$, suggesting the presence of dipolar interactions with the His(E7) center. This is consistent with the increase in the Fe-O energy and the kinetics studies on $\mathrm{Mb}$, which indicated that the hydrogen bond between His(E7) and the oxygen coordinated to the iron control the $k_{\text {off }}$ rate. The $\operatorname{Tyr}(\mathrm{B} 10)$ in the $\mathrm{HbI}_{L p} \mathrm{Phe}(\mathrm{B} 10) \rightarrow$ Tyr mutant and in $\mathrm{HbII}_{L p}$ is also stabilizing the coordinated dioxygen molecule as evidenced by the increase in the frequency from 567 to $571 \mathrm{~cm}^{-1}$, and to $572 \mathrm{~cm}^{-1}$, respectively, and the decrease in their dissociation rate constants from 61 to $0.6 \mathrm{~s}^{-1}$, and to $0.11 \mathrm{~s}^{-1}$, respectively. As mentioned above, despite similarities in their hydrogen bonding network, $\mathrm{Hb}_{\text {Asc }}$ and $\mathrm{HbII}_{L p}$ show significantly different oxygen dissociation rate constants (0.0041 and $0.11 \mathrm{~s}^{-1}$, respectively) $(2,48)$. Moreover, the $\mathrm{Hb}_{\text {Asc }}$ show a Fe-His normal mode at $202 \mathrm{~cm}^{-1}$, whereas for $\mathrm{HbII}_{L p}$ this frequency is present at $211 \mathrm{~cm}^{-1}$. Thus, differences in the His(F8) trans-effect and the orientation of the oxygen molecule in the oxyHbII $\mathrm{LP}_{L p}$ and oxyHb $\mathrm{H}_{\text {Asc }}$ complexes (Fig. 6) must have an important role to explain the observed experimental data. Similarly, this is also supported by studies of CO complexes showing three different conformers at 1912, 1956, and $1965 \mathrm{~cm}^{-1}$ for $\mathrm{Hb}_{A s c}-\mathrm{CO}$, whereas the $\mathrm{HbII}_{L p}-\mathrm{CO}$ complex show only the presence of the $\mathrm{A}_{3}$ and $\mathrm{A}_{0}$ conformers at 1924 and $1964 \mathrm{~cm}^{-1}$ in the infrared spectra $(15,46)$. Therefore, the interplay between the small $\mathrm{HbII}_{L p}$ heme pocket structure, the hydrogen bonding network to the proximal and distal heme environments, the His(F8) trans-effect, and the orientation of the oxygen molecule in the oxy complex are responsible for the stability of the oxyHbII ${ }_{L p}$ complex.

In truncated hemoglobins (trHbs), the oxy trHb complex shows, in general, a much lower energy for the Fe-O vibrational mode $\left(542-560 \mathrm{~cm}^{-1}\right)$ than $\mathrm{Mb}(49), \mathrm{HbI}_{L p}$, and $\mathrm{HbII}_{L p}$. Moreover, oxy trHbs tend to present an inverse correlation between the Fe-O frequency and the oxygen dissociation rate, similarly for oxyHbI $\mathrm{L}_{L p}$ and oxyHbII $\mathrm{Lp}_{L p}$ there is apparently also a rough inverse relationship with the dissociation constants but their Fe-O frequency is present at higher energy $\left(567-572 \mathrm{~cm}^{-1}\right)$. The fact that trHbs have a hydrogen bonding network interacting with the proximal and distal oxygens of the heme- $\mathrm{O}_{2}$ moiety, whereas $\mathrm{HbI}_{L p}$ and $\mathrm{HbII}_{L p}$ present a hydrogen bonding network interacting only with the distal oxygen of the oxyheme complex may account for the observed trend. Particularly, the $\mathrm{Fe}^{\delta+}-\mathrm{O}-\mathrm{O}^{\delta-}$ center is highly polar (50) and the formation of hydrogen bonding between heme pocket amino acids and one or both oxygens of the oxyheme complex can generate different moiety resonance structures. Furthermore, because the low frequency Fe-O Raman active vibrational mode arises from the interactions between the stretch and bend motion of $\mathrm{Fe}^{\delta+}{ }_{-} \mathrm{O}-$ $\mathrm{O}^{\delta-}$, at equilibrium, an approximate potential leading to the Fe-O vibrational frequency can be expressed as Equation 1,

$$
\begin{aligned}
V=f_{1} \Delta r_{1}{ }^{2}+f_{2} \Phi \Delta r_{2}{ }^{2} \pm f_{1} f_{2} \Delta r_{1} \Delta r_{2}+f_{\Phi} \Delta \Phi^{2} \\
\\
\pm f_{1} f_{\Phi} \Delta r_{1} \Delta \Phi \pm f_{2} f_{\Phi} \Delta r_{2} \Delta \Phi
\end{aligned}
$$

where $f_{1}, f_{2}, f_{\hat{\mathrm{O}}}, r_{1}, r_{2}$, and $\hat{\mathrm{O}}$ are the force constant and geometries for the Fe-O, O-O, and Fe-O-O atoms, respectively. Similarly, $f_{1} \mathrm{f}_{2}, f_{1} f_{\hat{\mathrm{O}}}$, and $f_{2} f_{\hat{\mathrm{O}}}$ are the associated interaction force constants, and their signs can be positive or negative $(51,52)$ depending on the $\mathrm{Fe}^{\delta+}-\mathrm{O}-\mathrm{O}^{\delta-}$ resonance structures, geometry, and central atom hybridization, which in turn are affected by the hydrogen bonding network present in the oxyhemoglobin species. It is plausible that the combination and magnitude of the sign in these coupling constants may be responsible for the lack of a single correlation between the Fe-O frequency and the hemeproteins oxygen dissociation constant.

Factors Influencing $\mathrm{HbII}_{L p}$ Oxygen Selection-Different roles have been suggested for the hemoglobin variants of $L$. pectinata $(1,3) . \mathrm{HbI}_{L p}$ is a sulfide-reactive monomeric protein, whereas $\mathrm{HbII}_{L p}$ and $\mathrm{HbIII}_{L p}$ are responsible for the oxygen transport and remain unaffected by the presence of $\mathrm{H}_{2} \mathrm{~S}$. The factors underlying this unique behavior and ligand selection between $\mathrm{HbI}_{L p}$ and $\mathrm{HbII}_{L p} / \mathrm{HbIII}_{L p}$ clearly depend on the heme iron oxidation state; however, the mechanism underlying the deoxy heme stability in $\mathrm{HbII}_{L p}$ is still unknown. In vitro $\mathrm{HbI}_{L p}$ and $\mathrm{HbII}_{L p}$ bind oxygen with an association rate constant of $100-$ $200 \times 10^{6}$ and $0.39 \times 10^{6} \mathrm{M}^{-1} \mathrm{~s}^{-1}$, and hydrogen sulfide with association rate constant values of $226 \times 10^{3}$ and $11.3 \times 10^{3}$ $\mathrm{M}^{-1} \mathrm{~s}^{-1}$, respectively $(2,3)$. This indicates that $\mathrm{HbI}_{L p}$ binds both ligands much faster than $\mathrm{HbII}_{L p}$. Similar to $\mathrm{HbII}_{L p}$, kinetic analysis of the $\mathrm{HbI}_{L p}$ Phe (B10) $\rightarrow$ Tyr mutant with $\mathrm{O}_{2}$ and $\mathrm{H}_{2} \mathrm{~S}$ indicates that in this variant the association constant of both ligands decreases to $6.8 \times 10^{6}$ and $3.37 \times 10^{3} \mathrm{M}^{-1} \mathrm{~s}^{-1}$, respectively, when compared with $\mathrm{HbI}_{L p}$. Furthermore, the $\mathrm{H}_{2} \mathrm{~S}$ dissociation constant for $\mathrm{HbII}_{L p}, \mathrm{rHbI}_{L p}$, and the $\mathrm{HbI}_{L p} \mathrm{Phe}(\mathrm{B} 10) \rightarrow \mathrm{Tyr}$ mutants are $17 \times 10^{-3}, 0.04 \times 10^{-3}$, and $0.06 \times 10^{-3} \mathrm{~s}^{-1}$, respectively, whereas for the oxygen species these values are $0.11,140$, and $0.6 \mathrm{~s}^{-1}$, respectively. Thus, the data indicate that in $\mathrm{HbI}_{L p}$ the Phe(B10) $\rightarrow$ Tyr mutation cannot account for the 


\section{L. pectinata Hbll Structure}

properties of $\mathrm{HbII}_{L p}-\mathrm{SH}_{2}$ complex reactivity but it can explain the smaller dissociation constant of oxyHbII ${ }_{L p}$. Replacing Phe(B10) by Tyr in the $\mathrm{HbI}_{L p}$ Phe(B10) $\rightarrow$ Tyr mutant may decrease the size of the $\mathrm{HbI}_{L p}$ heme cavity, thus causing a reduction in ligand association. Independently of the heme iron oxidation state driving force for the selection of $\mathrm{O}_{2}$ or $\mathrm{H}_{2} \mathrm{~S}$, the heme cavity of $\mathrm{HbII}_{L p}$ is smaller $\left(872 \AA^{3}\right)$ than the $\mathrm{HbI}_{L p}$. Dynamic features in $\mathrm{HbI}_{L p}, \mathrm{Mb}$, and triple $\mathrm{Mb}$ mutant (L29F/ H64Q/V68F) revealed a large cavity, suggesting that the larger cavities favor the binding of $\mathrm{H}_{2} \mathrm{~S}_{\text {by HbI}}$ (43). The reduction of the heme cavity of both $\mathrm{HbII}_{L p}$ and $\mathrm{HbI}_{L p} \mathrm{Phe}(\mathrm{B} 10) \rightarrow$ Tyr may help to stabilize the $\mathrm{Fe}^{\mathrm{II}}-\mathrm{O}_{2}$ moiety once $\mathrm{O}_{2}$ binds the heme iron center by forming hydrogen bonding interactions with $\mathrm{Gln}(\mathrm{E} 7)$ and $\operatorname{Tyr}(\mathrm{B} 10)$ as evidenced by the resonance Raman and oxygen off rate analyses presented above. Moreover, the reduction of the heme cavities in both proteins, caused in part by $\operatorname{Tyr}(\mathrm{B} 10)$, may help prevent oxidation of the ferrous iron center by impeding access of external water molecules into the distal environment. Indeed, a direct role of $\operatorname{Tyr}(\mathrm{B} 10)$ in preventing oxidation of $\mathrm{Fe}^{\mathrm{II}}$ as well as ligand selection can be observed in the $\mathrm{pH}$ titration analysis of $\mathrm{HbI}_{L p}, \mathrm{HbI}_{L p} \mathrm{Phe}(\mathrm{B} 10) \rightarrow \mathrm{Tyr}$, and $\mathrm{HbII}_{L p}$. The data showed that the high affinity of $\mathrm{HbII}_{L p}$ and the $\mathrm{HbI}_{L p}$ Phe(B10) $\rightarrow$ Tyr mutant for oxygen is $\mathrm{pH}$-dependent. Similarly, a decrease from $\mathrm{pH} 7.5$ to 5.5 was necessary to fully oxidize both $\mathrm{HbII}_{L p}$ and the $\mathrm{HbI}_{L p} \mathrm{Phe}(\mathrm{B} 10) \rightarrow$ Tyr mutant, suggesting that the tyrosine plays an important role in regulating the oxidation of the heme group. Previous experiments has been suggested a relationship between the $\mathrm{p} K_{a}$ values of the ionizable groups associated with the heme and the role of the hydrogen bonding interactions on the heme oxygen dissociation rate (53). Furthermore, for met-aquo $\mathrm{HbII}_{L p}$ and $\mathrm{HbI}_{L p} \mathrm{Phe}(\mathrm{B} 10) \rightarrow \mathrm{Tyr}$, the UV-visible $\mathrm{pH}$ data shows, at neutral conditions, bands at 486,541, 577, and $603 \mathrm{~nm}$ for both proteins. This suggests the existence of an open and closed conformation due to the interactions in the coordination of the $\operatorname{Tyr}(\mathrm{B} 10)(\mathrm{OH})$ and the ligand, to the heme iron. This means that, in the open conformation the $\operatorname{Tyr}^{30}(\mathrm{~B} 10)$ swings away from the iron, whereas in the closed conformation remains at very close distance and may interact with the ligand (47).

Overall, the data suggest a model for the in vivo mechanism of the clam L. pectinata where the function of $\mathrm{HbII}_{L p}$ to bind and possibly transport oxygen to the host bacteria is regulated by the dynamic displacements of the $\operatorname{Gln}^{65}$ (E7) and $\mathrm{Tyr}^{30}(\mathrm{~B} 10)$ pair toward the heme to protect it from the change in the heme oxidation state from $\mathrm{Fe}^{\mathrm{II}}$ to $\mathrm{Fe}^{\mathrm{III}}$. This suggested mechanism avoids the binding of $\mathrm{H}_{2} \mathrm{~S}$ to $\mathrm{HbII}_{L p}$ that disrupts its function of oxygen transport in an environment rich in hydrogen sulfide. In summary, the results from the crystallographic data show that a small heme pocket cavity for $\mathrm{HbII}_{L p}$ induces the formation of strong hydrogen bonds between the iron and oxygen molecule. Resonance Raman data supports the existence of a hydrogen bonding network between $\mathrm{Gln}(\mathrm{E} 7)$ and $\mathrm{Tyr}(\mathrm{B} 10)$ that stabilizes the binding of the oxygen to $\mathrm{HbII}_{L p}$ complex shown in Fig. 3. This, together with the proximal histidine trans-effect, and the $\mathrm{pH}$ dependence of the oxidation state substantiates the role of $\mathrm{HbII}_{L p}$ in controlling the oxygen dissociation rate.

\section{REFERENCES}

1. Read, K. R. (1965) Comp. Biochem. Physiol. 15, 137-157

2. Kraus, D. W., and Wittenberg, J. B. (1990) J. Biol. Chem. 265, 16043-16053

3. Kraus, D. W., Wittenberg, J. B., Lu, J. F., and Peisach, J. (1990) J. Biol. Chem. 265, 16054-16059

4. Rizzi, M., Wittenberg, J. B., Coda, A., Fasano, M., Ascenzi, P., and Bolognesi, M. (1994) J. Mol. Biol. 244, 86-99

5. Bolognesi, M., Rosano, C., Losso, R., Borassi, A., Rizzi, M., Wittenberg, J. B., Boffi, A., and Ascenzi, P. (1999) Biophys. J. 77, 1093-1099

6. Rizzi, M., Wittenberg, J. B., Coda, A., Ascenzi, P., and Bolognesi, M. (1996) J. Mol. Biol. 258, 1-5

7. Hockenhull-Johnson, J. D., Stern, M. S., Martin, P., Dass, C., Desidero, D. M., Wittenberg, J. B., Vinogradov, S. N., and Walz, D. A. (1991) J. Protein Chem. 10, 609-622

8. Torres, E., Renta, J. Y., Rodríguez, Y., López-Garriga, J., and Cadilla, C. L. (2003) J. Protein Chem. 22, 683-690

9. Pietri, R., Granell, L., Cruz, A., De Jesús, W., Lewis, A., León, R., Cadilla, C. L., and López Garriga, J. (2005) Biochim. Biophys. Acta 1747, 195-203

10. Yang, J., Kloek, A. P., Goldberg, D. E., and Mathews, F. S. (1995) Proc. Natl. Acad. Sci. U. S. A. 92, 4224-4228

11. Couture, M., Yeh, S., Wittenberg, B. A., Wittenberg, J. B., Ouellet, Y., Rousseau, D. L., and Guertin, M. (1999) Proc. Natl. Acad. Sci. U. S. A. 96, 11223-11228

12. Milani, M., Pesce, A., Ouellet, Y., Ascenzi, P., Guertin, M., and Bolognesi, M., (2001) EMBO J. 20, 3902-3909

13. Condon, P. J., and Royer, W. E., Jr. (1994) J. Biol. Chem. 269, 25259-25267

14. Royer, W. E., Jr., Heard, K. S., Harrington, D. J., and Chiancone, E. (1995) J. Mol. Biol. 253, $168-186$

15. Peterson, E. S., Huang, S., Wang, J., Miller, L. M., Vidugiris, G., Kloek, A. P., Goldberg, D. E., Chance, M. R., Wittenberg, J. B., and Friedman, J. M. (1997) Biochemistry 36, 13110-13121

16. De Jesús-Bonilla, W., Jia, Y., Alayash, A. I., and López Garriga, J. (2007) Biochemistry 46, 10451-10460

17. De Jesús-Bonilla, W., Cruz, A. Lewis, A., Cerda, J., Bacelo, D. E., Cadilla, C. L., and López-Garriga, J. (2006) J. Biol. Inorg. Chem. 11, 334-342

18. León, R. G., Munier-Lehmann, H., Barzu, O., Baudin-Creuza, V., Pietri, R., López-Garriga, J., and Cadilla, C. L. (2004) Protein Expr. Purif. 38, 184-195

19. Altschul, S. F., Madden, T. L., Schäffer, A. A., Zhang, J., Zhang, Z., Miller, W., and Lipman, D. J. (1997) Nucleic Acids Res. 25, 3389-3402

20. Thompson, J. D., Higgins, D. G., and Gibson, T. J. (1994) Nucleic Acids Res. 22, 4673-4680

21. Gavira, J. A., De Jesús, W., Camara-Artigas, A., Lopez-Garriga, J., and Garcia-Ruiz, J. M. (2006) Acta Crystallogr. Sect. F Struct. Biol. Crystallogr. Commun. 62, 196-199

22. García-Ruiz, J. M. (2003) Methods Enzymol. 368, 130-154

23. Otwinowski, Z., and Minor, W. (1997) Methods Enzymol. 276, 307-326

24. Brunger, A. T., Adams, P. D., Clore, G. M., Delano, W. L., Gros, P., GrosseKunstleve, R. W., Jiang, J. S., Kuszewski, J., Nilges, M., Pannu, N. S., Read, R. J., Rice, L. M., Simonson, T., and Warren, G. L. (1998) Acta Crystallogr. Sect. D Biol. Crystallogr. 54, 905-921

25. Bailey, S. (1994) Acta Crystallogr. Sect. D Biol. Crystallogr. 50, 760-763

26. Emsley, P., and Cowtan, K. (2004) Acta Crystallogr. Sect. D Biol. Crystallogr. 60, 2126-2132

27. Winn, M. D., Isupov, M. N., and Murshudov, G. N. (2001) Acta Crystallogr. Sect. D Biol. Crystallogr. 57, 122-133

28. Lovell, S. C., Davis, I. W., Adrendall, W. B., III, de Bakker, P. I., Word, J. M., Prisant, M. G., Richardson, J. S., and Richardson, D. C. (2003) Proteins 50, 437-450

29. Laskowski, R. A., MacArthur, M. W., Moss, D. S., and Thornton, J. M. (1993) J. Appl. Crystallogr. 26, 283-291

30. Frishman, D., and Argos, P. (1995) Proteins 23, 566-579

31. Hutchinson, E. G., and Thornton, J. M. (1996) Protein Sci. 5, 212-220

32. Kabsch, W. (1976) Acta Crystallogr. Sect. A 32, 922-923

33. Krissinel, E., and Henrick, K. (2005) Comput. Life Sci. Proc. 3695, 163-174

34. Hubbard, S. J., and Thornton, J. M. (1993) NACCESS, Computer Program, Department of Biochemistry and Molecular Biology, University College, London 


\section{L. pectinata Hbll Structure}

35. Binkowski, T. A., Naghibzadeh, S., and Liang, J. (2003) Nucleic Acids Res. 31, 3352-3355

36. Royer, W. E., Knapp, J. E., Strand, K., and Heaslet, H. A. (2001) Trends Biochem. Sci 26, 297-304.

37. Smerdon, S. J., Krzywda, S., Wilkinson, A. J., Brantley, R. E., Carver, T. E., Hargrove, M. S., and Olson, J. S. (1993) Biochemistry 32, 5132-5138

38. Royer, W. E., Jr., Pardanani, A., Gibson, Q. H., Peterson, E. S., and Friedman, J. M. (1996) Proc. Natl. Acad. Sci. U. S. A. 93, 14526-14531

39. Pardanani, A., Gambacurta, A., Ascoli, F., and Royer, W. E. (1998) J. Mol. Biol. 284, 729-739

40. Carver, T. E., Brantley, R. E., Jr., Singleton, E. W., Arduini, R. M., Quillin, M. L., Phillips, G. N., Jr., and Olson, J. S. (1992) J. Biol. Chem. 267, 14443-14450

41. Cerda, J., Echevarría, Y., Morales, E., and López-Garriga, J. (1999) Biospectroscopy 5, 289-301

42. Mukai, M., Mills, C. E., Poole, R. K., and Yeh, S. R. (2001) J. Biol. Chem. 276, 7272-7277

43. Fernández-Alberti, S., Bacelo, D. E., Binning, R. C., Echave, J., Chergui, M., and Lopez-Garriga, J., (2006) Biophys. J. 91, 1698 -1709
44. Zhou, Y. Q., Zhou, H. Y., and Karplus, M. (2003) J. Mol. Biol. 326, $593-606$

45. Das, K. T., Boffi, A., Chiancone, E., and Rousseau, A. D. (1999) J. Biol. Chem. 274, 2916-2919

46. Pietri, R., Granell, L. B., León, R., Cadilla, C. L., and López-Garriga, J. (2006) Biochim. Biophys. Acta 1764, 758-765

47. Navarro, A., Maldonado, M., González-Lagoa, J., López, R., López-Garriga, J., and Colón, J. (1996) Inorg. Chim. Acta 243, 161-166

48. Blaxter, M. L., Vanfleteren, J. R., Xia, J., and Moens, L. (1994) J. Biol. Chem. 269, 30181-30186

49. Lu, C., Egawa, T., Wainwright, L. M., Poole, R. K., and Yeh, S.-R. (2007) J. Biol. Chem. 282, 13627-13636

50. Hirota, S., Li, T., Phillips, G. H., Olson, J. S., Mukai, M., and Kitagawa, T. (1996) J. Am. Chem. Soc. 118, 7845-7846

51. Coulson, C. A., Duchesne, J., and Manneback, C. (1947) Nature 159, $794-795$

52. Califano, S. (1976) Vibrational States, pp. 95-97, John Wiley \& Sons, New York

53. Saroff, H. A. (2004) J. Theor. Biol. 229, 113-118 
Structure and Ligand Selection of Hemoglobin II from Lucina pectinata

José A. Gavira, Ana Camara-Artigas, Walleska De Jesús-Bonilla, Juan López-Garriga, Ariel Lewis, Ruth Pietri, Syun-Ru Yeh, Carmen L. Cadilla and Juan Manuel

García-Ruiz

J. Biol. Chem. 2008, 283:9414-9423.

doi: 10.1074/jbc.M705026200 originally published online January 18, 2008

Access the most updated version of this article at doi: 10.1074/jbc.M705026200

Alerts:

- When this article is cited

- When a correction for this article is posted

Click here to choose from all of JBC's e-mail alerts

Supplemental material:

http://www.jbc.org/content/suppl/2008/01/23/M705026200.DC1

This article cites 51 references, 11 of which can be accessed free at http://www.jbc.org/content/283/14/9414.full.html\#ref-list-1 